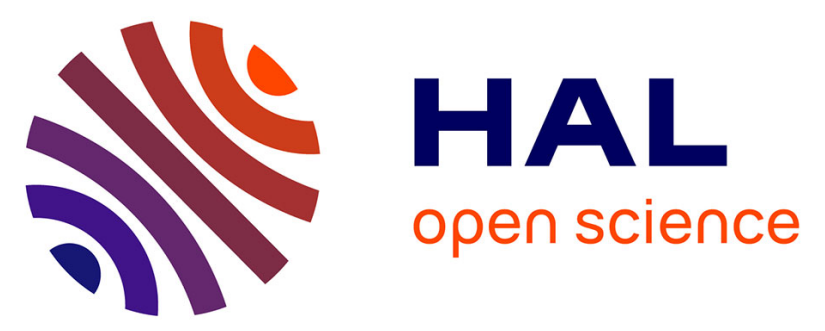

\title{
Potential role of the cannabinoid receptor CB1 in the pathogenesis of erosive and non-erosive gastro-esophageal reflux disease.
}

Carlo Calabrese, Enzo Spisni, Giuseppina Liguori, Giorgia Lazzarini, Maria Chiara Valerii, Antonio Strillacci, Paolo Gionchetti, Uberto Pagotto, Massimo Campieri, Fernando Rizzello

\section{To cite this version:}

Carlo Calabrese, Enzo Spisni, Giuseppina Liguori, Giorgia Lazzarini, Maria Chiara Valerii, et al.. Potential role of the cannabinoid receptor CB1 in the pathogenesis of erosive and non-erosive gastro-esophageal reflux disease.. Alimentary Pharmacology and Therapeutics, 2010, 32 (4), pp.603. 10.1111/j.1365-2036.2010.04377.x . hal-00552582

\section{HAL Id: hal-00552582 https://hal.science/hal-00552582}

Submitted on 6 Jan 2011

HAL is a multi-disciplinary open access archive for the deposit and dissemination of scientific research documents, whether they are published or not. The documents may come from teaching and research institutions in France or abroad, or from public or private research centers.
L'archive ouverte pluridisciplinaire HAL, est destinée au dépôt et à la diffusion de documents scientifiques de niveau recherche, publiés ou non, émanant des établissements d'enseignement et de recherche français ou étrangers, des laboratoires publics ou privés. 


\begin{tabular}{l}
\hline Alimentary Pharmacology \\
\hline \& Therapeutics \\
\hline
\end{tabular}

\section{Potential role of the cannabinoid receptor CB1 in the pathogenesis of erosive and non-erosive gastro-esophageal reflux disease.}

\begin{tabular}{|c|c|}
\hline Journal: & Alimentary Pharmacology \& Therapeutics \\
\hline Manuscript ID: & APT-0289-2010.R1 \\
\hline Manuscript Type: & Original Scientific Paper \\
\hline $\begin{array}{r}\text { Date Submitted by the } \\
\text { Author: }\end{array}$ & 19-May-2010 \\
\hline Complete List of Authors: & $\begin{array}{l}\text { Calabrese, Carlo; University of Bologna, Internal Medicine and } \\
\text { Gastroenterology } \\
\text { Spisni, Enzo; University of Bologna, Biology } \\
\text { Liguori, Giuseppina; University of Bologna, Internal Medicine and } \\
\text { Gastroenterology } \\
\text { Lazzarini, Giorgia; University of Bologna, Biology; University of } \\
\text { Bologna, Internal Medicine and Gastroenterology } \\
\text { Valerii, Maria Chiara; University of Bologna, Biology; University of } \\
\text { Bologna, Internal Medicine and Gastroenterology } \\
\text { Strillacci, Antonio; University of Bologna, Biology } \\
\text { Gionchetti, Paolo; University of Bologna, Polyclinic S. Orsola, } \\
\text { Department of Internal Medicine and Gastroenterology } \\
\text { Pagotto, Uberto; University of Bologna, Internal Medicine and } \\
\text { Gastroenterology } \\
\text { Campieri, Massimo; University of Bologna, Internal Medicine and } \\
\text { Gastroenterology } \\
\text { Rizzello, Fernando; University of Bologna, Internal Medicine and } \\
\text { Gastroenterology }\end{array}$ \\
\hline Keywords: & $\begin{array}{l}\text { GERD or GORD < Disease-based, Oesophagus < Organ-based, } \\
\text { Acidity (oesophageal) < Topics, Basic science < Topics, } \\
\text { Histopathology < Topics, Outcomes research < Topics }\end{array}$ \\
\hline
\end{tabular}

\section{(5) ScholaroNE


Potential role of the cannabinoid receptor CB1 in the pathogenesis of erosive and non-erosive gastro-esophageal reflux disease.

Carlo Calabrese MD, PhD ${ }^{l}$, Enzo Spisni PhD ${ }^{2}$, Giuseppina Liguori MD, PhD student ${ }^{1}$, Giorgia Lazzarini PhD student ${ }^{1-2,}$ Maria Chiara Valerii PhD student ${ }^{1-2}$, Antonio Strillacci PhD ${ }^{2}$, Paolo Gionchetti $\mathrm{MD}^{1}$, Uberto Pagotto $\mathrm{MD}, \mathrm{PhD}^{1}$, Massimo Campieri $\mathrm{MD}^{1}$, Fernando Rizzello $\mathrm{MD}$, $P h D^{1}$

${ }^{1}$ Department of Clinical Medicine, University of Bologna, Italy

${ }^{2}$ Department of Biology, University of Bologna

Short title: Role of CB1 in ERD and NERD

Keywords: CB1 receptor, GERD, NERD, ERD, mucosa esophageal defenses

\author{
Corresponding Author: \\ Carlo Calabrese, via Massarenti 9, 40138 Bologna, Italy \\ Tel. +390516364191 Fax +39051392538 \\ E-mail: carlo.calabrese2@unibo.it
}




\begin{abstract}
Background: Cannabinoid $(\mathrm{CB})$ receptors have been located in brain areas involved in the triggering of TLESRs as well as in the nodose ganglion from which vagal afferents emanate. The distribution of $\mathrm{CB}_{1}$ receptors has been investigated in the human gastrointestinal mucosa, as expression of inflammatory process.

Aim: To evaluate the $\mathrm{CB}_{1}$ expression in esophageal mucosa.

Methods: 87 consecutive subjects were enrolled: 10 controls, 39 NERD and 38 erosive esophagitis. Eight specimens were taken from macroscopically normal mucosa. Five were processing by hematoxylin-eosin, MIB1/CB1 evaluation and 3 for the RNA and proteins extraction.

Results: the mean MIB1-LI value was $31 \%$ and $22 \%$ in NERD and ERD patients respectively, compared to $68 \%$ in the healthy subjects. Mean $\mathrm{CB}_{1}$ mRNA/GUSB mRNA value of the controls was 0.66 while in GERD patients was 0.28 . In NERD and ERD, the mean of $\mathrm{CB}_{1} / \mathrm{GUSB}$ were 0.38 and 0.17, respectively, with highly significant differences between the NERD vs. ERD groups. Semiquantitative analysis of $\mathrm{CB}_{1}$ expression, performed with $\mathrm{WB}$, shows in NERD patients a higher $\mathrm{CB}_{1}$ receptor expression than ERD patients.
\end{abstract}

Conclusions: with this study we showed for the first time the presence of CB1 receptors in the human esophageal epithelium. 


\section{Introduction}

An essential concept in the pathogenesis of gastroesophageal reflux disease (GERD) is that the extent of symptoms and of mucosal injuries is proportional to the frequency of reflux events, the duration of mucosal acidification, and the caustic strength of refluxed fluid. The integrity of the esophageal mucosa in normal healthy individuals reflects the balance between injurious forces (acid reflux, potency of refluxate) and defensive forces (esophageal clearance, mucosal defense). For several reasons, this balance becomes impaired in patients who develop GERD (1-2).

The primary event in the pathogenesis of GERD is the movement of gastric juice from the stomach into the esophagus. The antireflux barrier at the gastroesophageal junction is anatomically and physiologically complex and vulnerable to several potential mechanisms of reflux.

Acid and bile exposure times in GERD patients who are endoscopically negative (NERD) and in subjects with erosive esophagitis (ERD) greatly overlap, as demonstrated by 24-h monitoring methodologies and ultrastructural alterations (3-5). This strongly implies that there must be other factors that influence the degree of macroscopic and microscopic changes within the esophageal mucosa under the impact of the aggressive milieu of the gastroesophageal refluxate.

Esophageal mucosal defense mechanisms, balancing luminal aggressive factors, operate at three overlapping levels: the pre-epithelial barrier, the epithelial barrier and the post-epithelial barrier; the latter is represented by the lamina propria. Although, much is known about the pre-epithelial mucus barrier (6-8), epithelial defense mechanisms remain poorly understood (9).

We have previously shown that in patients affected by GERD, the proliferation rate of the esophageal epithelium was reduced and, in particular, NERD patients showed a decrease of 50\% in the epithelial proliferative activity, while ERD patients showed a decrease of $75 \%$, when compared to normal subjects (10). Yet, the molecular mechanism at the basis of this phenomenon remains largely unknown. 
Cannabinoid (CB) receptors belong to the superfamily of G-protein-coupled receptors (11-12). There are two types of $\mathrm{CB}$ receptors, the type $1\left(\mathrm{CB}_{1}\right)$ and the type $2\left(\mathrm{CB}_{2}\right)$ receptors. In the GI tract, $\mathrm{CB}_{1}$ receptor is expressed in neurons of the enteric nervous system and in sensory terminals of vagal and spinal neurons, and its functions include control of secretion, intestinal motility, neurotransmitter release and proliferation (13-15). $\mathrm{CB}_{2}$ receptors have been located mainly in the immune cells associated to the gut.

$\mathrm{CB}_{1}$ receptors expressions have been also found in non neuronal sites, including adipocytes, endothelial cells, smooth muscle and colonocytes. In colonic epithelial cell lines and in primary colonic epithelial cells, $\mathrm{CB}_{1}$ receptor stimulation initiates several downstream signal transduction pathways that include ERK1 and ERK2 phosphorylation (16). As a consequence, its physiological role has been proposed to include colonocytes proliferation and epithelial wound healing. An increased epithelial expression of $\mathrm{CB}_{1}$ has been observed in intestinal biopsies of patients with active inflammatory bowel diseases (IBD) (16). The involvement of $\mathrm{CB}_{1}$ receptors in modulating gut inflammation and epithelial injuries has been evidenced in experimental models of IBDs, in which $\mathrm{CB}_{1}$ agonists reduce colon shrinkage, diarrhoea, colon inflammatory damages and histological damages through the inhibition of $\mathrm{TNF} \alpha$ production. (17). Moreover, in $\mathrm{CB}_{1}$-deficient mice experimentally induced colitis was more severe than in wild-type mice (18).

Recently, Beaumont et al (19) showed that $\Delta$ 9-tetrahydrocannabinol ( $\Delta 9$-THC), a cannabinoid receptor agonist, is able to reduce the transient lower esophageal sphincter relaxations (TLESRs), in humans.

The distribution of $\mathrm{CB}_{1}$ receptors has been investigated in the human gastrointestinal mucosa, as expression of inflammatory process. To date there are no studies that evaluated the $\mathrm{CB}_{1}$ expression in esophageal mucosa.

The aim of this study was to evaluate the presence of $\mathrm{CB}_{1}$ receptors in the esophageal epithelium of patients with NERD and ERD compared to healthy subjects. 


\section{Material and methods}

\section{Study populations}

One hundred and ten consecutive patients with GERD-related symptoms were evaluated for the enrollment into the study. Inclusion criteria were the presence of typical symptoms (heartburn and/or regurgitation) for at least 1 year (frequency was more than 2 times a week) and abnormal 24h $\mathrm{pH}$ parameters and symptom-association probability (SAP). Exclusion criteria were patients with esophageal or gastric malignancy or histological proven Barrett esophagus, gastric or duodenal ulcer, previous esophageal or gastric surgery, extraesophageal symptoms, patients taking antisecretory or prokinetic drugs at least 30 and 15 days before procedure, respectively. Seventy-seven patients (mean age $45.2 \pm 13.4$ years, range $21-80,35$ men) fulfilled the inclusion/exclusion criteria and evaluated into the study (fig. 1). All these patients underwent to a standard endoscopy and biopsy for histological evaluation. Of them, 39 had an apparently normal esophageal mucosa at endoscopy (NERD), while 38 had erosive esophagitis (ERD) (tab. 1). This population was compared with 10 healthy voluntary controls (mean age $38.2 \pm 17.6$ years, range 25-63, 6 men) defined as the absence of typical symptoms or atypical manifestations of GERD, normal questionnaire score, no evidence of esophageal mucosal lesions on standard resolution endoscopy, and normal 24-hour acid exposure (mean total acid reflux time was $1.1 \% \pm$ $0.4 \%)$.

The frequency and intensity of symptoms and their impact on the patients' quality of life were registered using a structured and validated questionnaire for the diagnosis of GERD (20), and patients with a score higher than 3.1 were considered positive.

Patients gave written informed consent to participate in the study, which was approved by the local research ethical committee. more than 8 weeks in the last year). 


\section{Twenty-four-hour ambulatory pH monitoring}

Every patient underwent 24-h esophageal $\mathrm{pH}$ monitoring according to standard methodology. During the test day, mealtime and composition were standardized. The reflux parameters were assessed according to Johnson and DeMeester (21). Of them, only the percentage of time spent at $\mathrm{pH}<4.0$ over $24 \mathrm{~h}$ was evaluated. $\mathrm{pH}$ testing was considered abnormal if $\mathrm{pH}<4.0$ was present for more than $5 \%$ of the total 24-h time. The SAP was calculated according to Weusten et al. (22) and was considered positive if it exceeded $95 \%$.

\section{Endoscopic evaluation}

Patients underwent upper GI endoscopy (videogastroscope Olympus GIF 140) after sedation by i.v. administration of midazolam $(2,5 \mathrm{mg})$ to assess the presence or absence of erosive esophagitis. The Los Angeles classification was used to grade esophagitis (23). In each subject, 8 specimens were taken with standardized biopsy forceps (Olympus FB 24K), from each of the four quadrants, two bites from each quadrant, $5 \mathrm{~cm}$ above the squamo-columnar junction (SCJ), from macroscopically intact (non-eroded) esophageal mucosa. The SCJ (or Z-line) was defined as the border between gastric glandular and esophageal squamous epithelium and it roughly corresponded to the proximal edge of gastric folds.

Of among the 8 specimens taken, 5 were oriented to appropriate cellulose acetate supports (Endofilters Bioptica, Milan, Italy), fixed in $4 \%$ buffered formalin and embedded in paraffin, for processing by hematoxylin-eosin for histology, MIB1 and CB1 evaluation, 3 were immediately put in liquid nitrogen and stored at $-80^{\circ} \mathrm{C}$ for the RNA and proteins extraction.

\section{Histological evaluation}

Four micrometres-thin serial sections were cut from each paraffin block and stained with haematoxylin-eosin. For each case, whole longitudinally sectioned samples were examined. Esophagitis was identified and graded according to the Ismail-Beigi et al. classification (24):

1. The degree of basal cell hyperplasia, expressed as a percentage of epithelial thickness: none (0-15\%), mild (16-33\%), moderate (34-67\%), severe (>67\%); 
2. The presence or absence of papillary zone elongation, determined by calculating papillary length as a percentage of epithelial thickness: absent $(0-67 \%)$ and present $(>67 \%)$;

3. The density of neutrophil and eosinophil infiltration: none (0/high power field), mild (12/high power field), moderate 3-10/high power field) and severe ( $>10 /$ high power field). The area of one high power field was $0.229 \mathrm{~mm}$.

\section{Immunohistochemical Analysis}

Biopsies were fixed in $4 \%$ buffered formalin and embedded in paraffin. Tissue sections (3- $\mu \mathrm{m})$ were mounted on slides, sections were deparaffinised with xylene and rehydrated through a series of graded alcohols, then were blocked in 5\% bovine serum albumin in Phosphate-buffered saline (PBS) for $1 \mathrm{~h}$ and incubated overnight at $4{ }^{\circ} \mathrm{C}$ with $\mathrm{CB}_{1}$ and $\mathrm{CB}_{2}$ antibody (Cayman Chemicals, USA) at a 1:500 dilution in PBS. For control slides, primary antibody was omitted or blocking peptide was used as suggested by the manufacturer (Cayman Chemicals, USA). Sections then were incubated in rabbit-specific secondary antibody for 30 minutes at room temperature and then in 3,3diaminobenzidine tetrahydrochloride (DAKO) for 4 minutes. Sections were counterstained with haematoxylin/eosin.

\section{MIB1 immunostaining and quantification}

MIB1 immunostaining was assessed using anti-Ki-67 monoclonal antibodies (MoAbs) (clone MIB1; BioGenex Laboratories, San Ramon, CA, USA). Before immunostaining, antigen retrieval was effected by heating the slides, which were fully immersed in $10 \mathrm{mM}$ sodium citrate buffer ( $\mathrm{pH}$ 6.0) for $20 \mathrm{~min}$ in an autoclave. After cooling down to room temperature, slides were incubated with primary MoAbs overnight at a dilution of 1:100. The immunostaining reaction was then developed according to SABC (stretavidin-biotin-peroxidase pre-formed complex) protocol and highlighted using a peroxidase/DAB enzymatic reaction. Sections were finally counterstained with haematoxylin/eosin. Quantitative analysis of MIB1 immunostaining was performed on contiguous field visualized on the color monitor of a Pentium III PC equipped with a 3 CCD (charge-couple 
device) color video camera (KY F55B, JVC, Pinebrook, NJ, USA) connected to a light microscope (Leitz DIAPLAN). For each case, whole longitudinally sectioned samples were examined. Samples that did not contain at least 1000 cells were excluded. Quantitative evaluation was only carried out on portions of epithelium in between vertically sectioned stromal papillae, and corresponding to 100 $\mu \mathrm{m}$ from the basal layer. The MIB1 label index (MIB1-LI) was defined as the ratio of MIB1 positive nuclei to the total number of epithelial cells, and was expressed as a percentage.

RNA extraction and real-time PCR

Total RNA from biopsies was extracted using Eurozol reagent (CELBIO, Italy) according to the manufacturer's instructions. Extracted RNA samples were quantified, treated with DNase I to remove any genomic DNA contamination using DNA-free kit (Ambion, USA) and reversetranscripted using RevertAid ${ }^{\mathrm{TM}}$ First Strand cDNA Synthesis Kits (Fermentas, Canada). $\mathrm{CB}_{1}$ and $\mathrm{CB}_{2}$ mRNA levels were analyzed by real-time PCR using SYBR supermix kit and Bio-Rad iCycler system (Bio-Rad, USA) according to the manufacturer's instructions. Colon mucosa were used as positive controls. The melting curve data were collected to check PCR specificity. Each cDNA sample was analyzed as triplicate. $\mathrm{CB}_{1}$ mRNA levels were normalized against $\beta$-glucuronidase (GUSB) mRNA. Relative expressions were calculated using the formula $2^{-2 \Delta \mathrm{Ct}}$ values $\left(\Delta \mathrm{Ct}=\mathrm{Ct}_{\mathrm{CB} 1}\right.$ - $\mathrm{Ct}_{\mathrm{GUSB}}$ ). $\mathrm{CB}_{1}$ primer pair: 5' ${ }^{-}$TATGCTCTGCCTGCTGAAC-3' and 5'TGACCGTGCTCTTGATGC-3' (215 bp product); $\quad \mathrm{CB}_{2}$ primer pair: 5'TTGGCAGCGTGACTATGAC-3' and 5'-GAGGAAGGCGATGAACAGG-3' (275 bp product); GUSB primer pair: 5'-TGGTATAAGAAGTATCAGAAGCC-3' and 5'GTATCTCTCTCGCAAAAGGAAC-3’ (297 bp product).

\section{Western blot}

Biopsies were homogenized in lysis buffer (50 mM Tris-HCl, pH 7.5, 2 mM EDTA, 100 mM NaCl, $1 \%$ Triton X-100 and protease inhibitors mixture). Lysates were incubated $1 \mathrm{~h}$ on ice and 
centrifuged at $12000 \mathrm{~g}$ to collect supernatants. After addition of SDS-PAGE sample buffer and boiling, $50 \mu \mathrm{g}$ of denatured proteins were separated in $12 \%$ SDS-PAGE and then transferred to PVDF membranes. After the blotting, PVDF membranes were incubated with primary antibodies. The primary antibodies used were: polyclonal anti- $\mathrm{CB}_{1}$ (Sigma, USA), anti-CB $\mathrm{CB}_{2}$ (Cayman, USA) and anti- $\beta$-actin (Sigma, USA). Secondary antibodies (Cy3-conjugated) were purchased from GE, USA. Immunolabelling was visualized using the ECL-plex procedure, according to manufacturer instructions (GE, USA). PVDF membrane were digitalized by using dedicated scanner (Pharos FX, BioRad, USA). Bands were quantified using densitometric image analysis software (Quantity One, Bio-Rad, USA). Normalization was made against $\beta$-actin expression.

\section{Statistics}

Student's T-test was performed for both independent variables. The Mann-Whitney U test was performed to compare cell kinetics data in each group of subjects. A $P<0.05$ was considered statistically significant. Data were analyzed with SPSS software (SPSS, Chicago, IL). 


\section{Results}

At histology, among 38 patients affected by erosive esophagitis in endoscopic normal mucosa, 30 had a normal pattern, and 8 had mild esophagitis. Only one patient with NERD showed histological signs of esophagitis (mild) (tab. I).

\section{$C B_{1}$ Immunostaining}

Immunocytochemical staining with $\mathrm{CB}_{1}$ antibody shows the presence of $\mathrm{CB}_{1}$ receptor in esophageal mucosa of both healthy subject and GERD patients. A weak positivity is localized in mature squamous cells (Fig. 2A, black arrow) and in connectival papillae (Fig. 2A, red arrows) of healthy mucosa. In NERD patients a strong positive staining is evident in mature squamous cells (Fig. 2B, black arrow), in squamous cells (Fig. 2B, blue arrow) and in connectival papillae (Fig 2B, red arrow). In ERD patients, positive stain pattern includes mature squamous cells (Fig. 2C, black arrow) and squamous cells (Fig. 2C, blue arrows), while connectival papillae appear negative. No positive $\mathrm{CB}_{2}$ staining was observed in GERD patients

\section{MIB1 immunostaining and quantification}

Proliferating cells were located mainly in the basal zone (100 $\mu \mathrm{m}$ from the basal layer) in the three groups, with no differences in their architectural distribution towards the mucosa. MIB1-LI ranged from 12 to $78.8 \%$ among all subjects, with a mean $( \pm$ SD) value of $31.6 \%( \pm 15.8)$ and a median value of $25.6 \%$. The mean MIB1-LI values of the health voluntary controls was $67.8 \%( \pm 9.87)$ while in GERD patients was 27\% $( \pm 9.1)$. In NERD and ERD patients, the mean of MIB1-LI were $31.3 \%( \pm 8.7)$ and $22.6 \%( \pm 7.3)$, respectively, with highly significant differences among the groups $(\mathrm{p}<0.001)$ (fig. 3).

\section{RNA extraction and real-time PCR}

Real time PCR analysis shows that in patients with ERD, the relative expression of $\mathrm{CB}_{1}$ mRNA, in esophageal mucosa, is strongly decreased in comparison to NERD patients. In particular, the 
relative expression of $\mathrm{CB}_{1}$ mRNA in NERD mucosa is three fold higher, and show elevated variability between patients, with respect to ERD mucosa. In healthy mucosa, $\mathrm{CB}_{1} \mathrm{mRNA}$-relative expression is not significantly different from NERD mucosa. Relative expression of $\mathrm{CB}_{1}$ mRNA/GUSB mRNA ranged from 0.5 to 0.968 among all subjects with a mean $( \pm \mathrm{SD})$ value of 0.32 ( \pm 0.28 ). The mean $\mathrm{CB}_{1}$ mRNA/GUSB mRNA value of the health voluntary controls was 0.66 $( \pm 0.28)$ while in GERD patients was $0.28( \pm 0.24)$. In NERD and ERD patients, the mean of $\mathrm{CB}_{1} /$ GUSB were $0.38( \pm 0.3)$ and $0.17( \pm 0.09)$, respectively, with highly significant differences between the NERD vs. ERD groups ( $\mathrm{p}<0.001$ ) (fig. 4). $\mathrm{CB}_{2}$ mRNA was not detectable in GERD biopsies.

\section{Western blot}

Semi-quantitative analysis of $\mathrm{CB}_{1}$ expression, performed with Western blotting, shows a different expression of $\mathrm{CB}_{1}$ receptor between ERD and NERD mucosa. In particular, NERD patients shows a higher $\mathrm{CB}_{1}$ receptor expression than ERD patients (fig. 5 A) Relative expression of $\mathrm{CB}_{1} / \beta$-actin ranged from 59 to 125 among all subjects with a mean $( \pm$ SD) value of $84.7( \pm 18.8)$ and a median value of 82.7 . The mean $\mathrm{CB}_{1} / \beta$-actin values of the health voluntary controls was $68.9 \%( \pm 5.9)$ while in GERD patients was 86.7 ( \pm 18.9). In NERD and ERD patients, the mean of $\mathrm{CB}_{1} / \beta$-actin were $99.9( \pm 15.8)$ and $73.3( \pm 10.5)$ respectively, with highly significant differences among the NERD vs control and ERD groups ( $<$ < 0.001) (fig. 5 B). $\mathrm{CB}_{2}$ protein was not detectable in GERD biopsies. 


\begin{abstract}
Discussion
The present study provide for the first time evidence of the expression of $\mathrm{CB}_{1}$ receptors in the human esophageal epithelium. Moreover, we show here that $\mathrm{CB}_{1}$ receptor is differentially expressed in GERD patients with erosive or non erosive esophagitis.
\end{abstract}

A growing evidence suggest that erosive endoscopic changes within the esophageal mucosa in patients with GERD accompanied by reflux esophagitis result from a disequilibrium between aggressive factors and protective mechanisms (25-26). Because aggressive factors seem to operate in the same way in NERD than in ERD patients, it is reasonable to suppose that the protective mechanisms play a pivotal role in the development of histological injuries.

In this study biopsies were taken only in apparently normal mucosa. In this way we studied the behavior of the mucosa exposed to chronic acid insult, but far from erosions and, especially, from reparative changes secondary to the lack of the superficial mucosa, where basal cells hyperplasia and elongation of rate pegs have been reported (24). Biopsies were taken from the esophagus only at $5 \mathrm{~cm}$ above the Z-line and not in the very distal part of the esophagus. In fact, it has been argued in other works that histological changes like basal cell hyperplasia, increased papillary length, may occur from minor degrees of 'physiological reflux': this phenomena would limit applicability of biopsies next to the Z-line determining a decreased sensitivity of the evaluation (27-29). Moreover, the proximal part of the esophagus has not taken in consideration. At this level overall reflux event is minor compared to the distal esophagus (approximately, ranging from $15 \%$ to $30 \%$ of overall reflux events in patients with GERD respects to controls, round $10 \%$ of episodes) with the possibility of a drop in specificity of data obtained (30-32).

We have previously shown that esophageal mucosa of patients with reflux symptoms and erosive esophagitis present a decreased proliferative activity in comparison with non erosive esophagitis (10). To assess the cell proliferation rate of the epithelium, we measured the number of proliferating cells by using MIB1 immunolabeling (33). In all our patients with macroscopically normal mucosa, 
esophageal epithelium exposed to chronic acid refluxate showed a significantly lower number of proliferating cells if compared to healthy normal subjects. In particular, the mean MIB1-LI value was $31 \%$ and $22 \%$ in NERD and ERD patients respectively, compared to $68 \%$ in the healthy subjects. To note that $\mathrm{pH}$-monitoring in our ERD and NERD patients did not reveal statistically significant differences, whilst the proliferation capability was statistically lower in ERD patients than in NERD patients. This observation confirms that acid and pepsin insults are necessary to determine damage, in particular at ultrastructural level, i.e. dilation of intercellular spaces (34-35), but the cell proliferation capability of the mucosa could be a key factor that can switch the disease to either one or the other form.

Recently, we showed that PPI treatment, reducing the chronic acid-peptic insult, is able to improve esophageal cell proliferation and that long-term PPI treatment could be helpful in increasing the esophageal epithelial proliferation in GERD (36).

Two reasonable hypotheses could be suggested to explain the reduced epithelial proliferation activity observed in GERD: either the chronic cell damage induced by gastroesophageal reflux determines a reduction in the proliferation rate of esophageal epithelium, or a constitutive lower capability for cell proliferation brings a major susceptibility to damages induced by gastroesophageal reflux.

Patients with more efficient epithelial proliferation capability could have a lower probability of developing macroscopic mucosal lesions when stressed by acid and pepsin. A possible genetic influence in the proliferation capability of the mucosa has a certain appeal.

There is good evidence that endocannabinoids and CB1 receptors are upregulated during intestinal inflammation (37-38) and that enhanced endocannabinoid production, acting mostly through CB1 receptors, can decrease motility during intestinal inflammation $(18,39)$ and protect against epithelial damage (16). Similarly, our data demonstrate that $\mathrm{CB}_{1}$ receptor expression is increased in esophageal mucosa of NERD patients in comparison to ERD ones. Real-time PCR analyses show that in ERD and NERD patients, the expression of $\mathrm{CB}_{1}$ mRNA is decreased, in comparison to 
control mucosa. In particular, the expression of $\mathrm{CB}_{1}$ mRNA in NERD esophageal mucosa is more than twofold higher, in comparison with ERD mucosa. These data correlate with Western blotting results, indicating that the expression of $\mathrm{CB}_{1}$ receptor, at protein level, is 1.4 fold higher fold in NERD, in comparison than ERD patients. Moreover, the mean relative expression of $\mathrm{CB}_{1}$ receptor and $\mathrm{CB}_{1}$ mRNA in the NERD group shows higher variability between patients, with respect to ERD group. While at mRNA level we observed a strong decrease of $\mathrm{CB}_{1}$ mRNA expression in GERD mucosa, in comparison to healthy subjects, at protein level healthy subject and ERD mucosa show similar $\mathrm{CB}_{1}$ expression levels, while NERD patients show increased $\mathrm{CB}_{1}$ receptor levels. These discrepancies in mRNA/protein ratio between GERD affected and healthy mucosa underline that different $\mathrm{CB}_{1}$ mRNA regulatory pathways exist in GERD affected patients. It is very likely that the inflammatory microenvironment that characterize GERD affected mucosa (40) alter $\mathrm{CB}_{1}$ gene expression, through micro RNAs regulation of the translational machinery, as it has been recently suggested (41).

Recently, Wright et al (16) have underlined a proliferative activity of the $\mathrm{CB}_{1}$ in normal human colon epithelium. In particular, it has been reported that the colonic epithelial cell lines can respond to synthetic and endogenous cannabinoids through the phosphorylation of ERK, PKB and GSK3 $\alpha / \beta$ and that these events are $\mathrm{CB}_{1}$-mediated. Our findings are in agreement with the results of this study. We showed that $\mathrm{CB}_{1}$ receptors are expressed preferentially in the mature squamous cells of esophageal epithelium while $\mathrm{CB}_{2}$ receptor levels are undetectable in esophageal mucosa. These studies strengthen the hypothesis of a physiological role of the endocannabinoid system in the human gastrointestinal tract and confirm that $\mathrm{CB}_{1}$ receptors could be also involved in the esophageal mucosa defense mechanisms.

In conclusion, the immunocytochemical staining, real-time PCR and WB analyses confirm that $\mathrm{CB}_{1}$ receptor is expressed in esophageal mucosa, and strengthen the hypothesis that its expression may have a physiopathological role in the response of the epithelium to reflux injuries. Further studies 


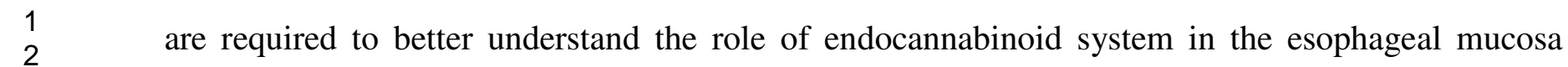
3 defense mechanisms. 
Table I: demographic, endoscopic, histologic and 24-h esophageal $\mathrm{pH}$ monitoring data of the studied population

\begin{tabular}{lccc} 
& Normal & NERD & ERD \\
\hline $\mathrm{N}^{\circ}$ of subjects & 10 & 39 & 38 \\
Sex $(\mathrm{m} / \mathrm{f})$ & $6 / 4$ & $17 / 22$ & $18 / 20$ \\
Mean age \pm SD (range) & $38.2 \pm 17.6(25-63)$ & $48.4 \pm 14.6(22-80)$ & $42.1 \pm 12.3(21-70)$
\end{tabular}

\section{Endoscopy}

Normal

10

39

0

A

0

0

0

B

0

0

28

C

0

0

9

D

0

0

1

\section{Histology}

Normal

10

38

30

Mild

0

1

8

Moderate

0

0

0

Severe

0

0

0

\section{4-h pH monitoring}

Mean \% of acid

$0.9( \pm 0.5)$

$10.1( \pm 1.2)$

$10.6( \pm 1.2)$

exposure time $( \pm S D)$

$9( \pm 3)$

$128( \pm 21)$

$127( \pm 22)$ 
Figure 1: Study profile

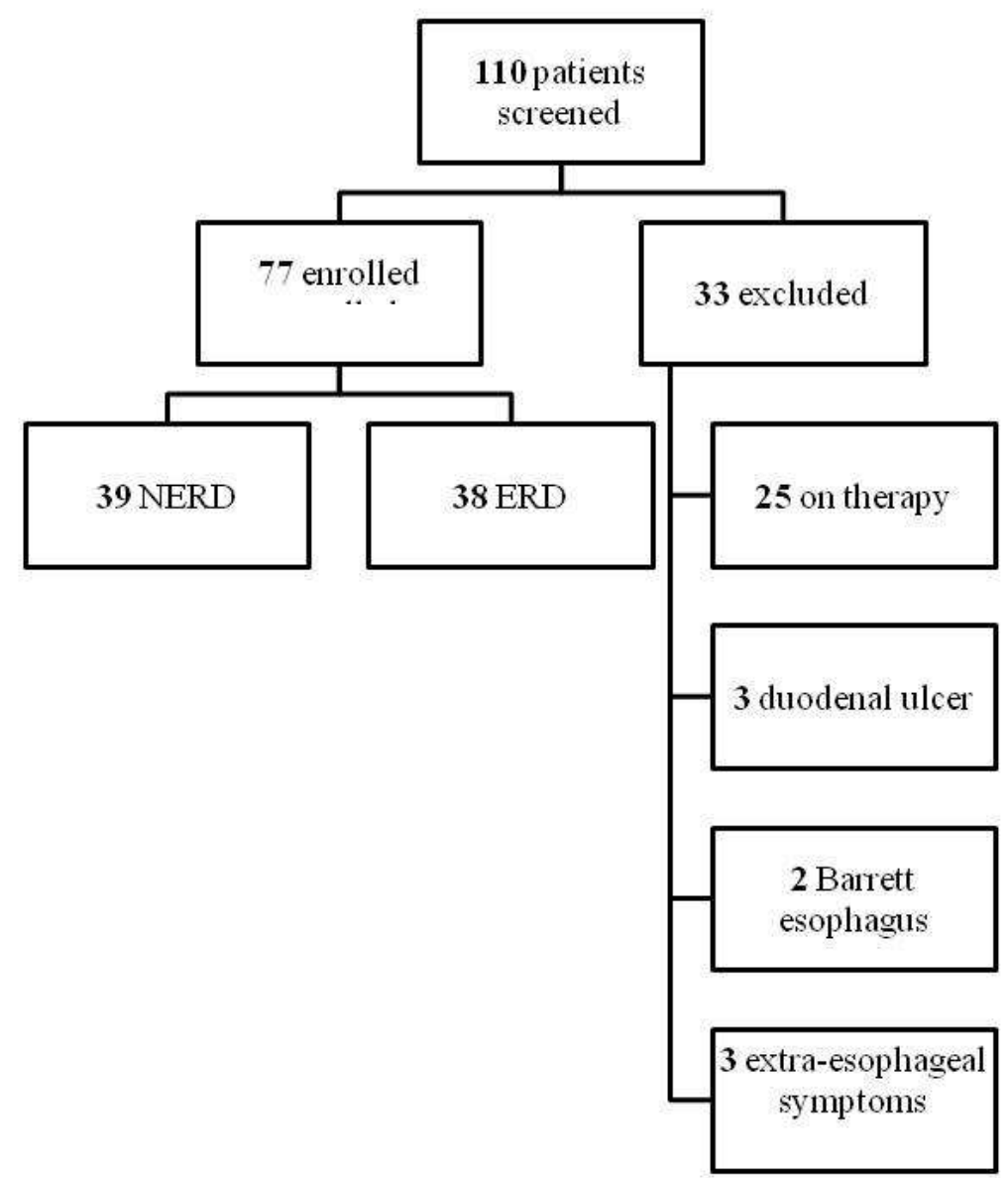

2 


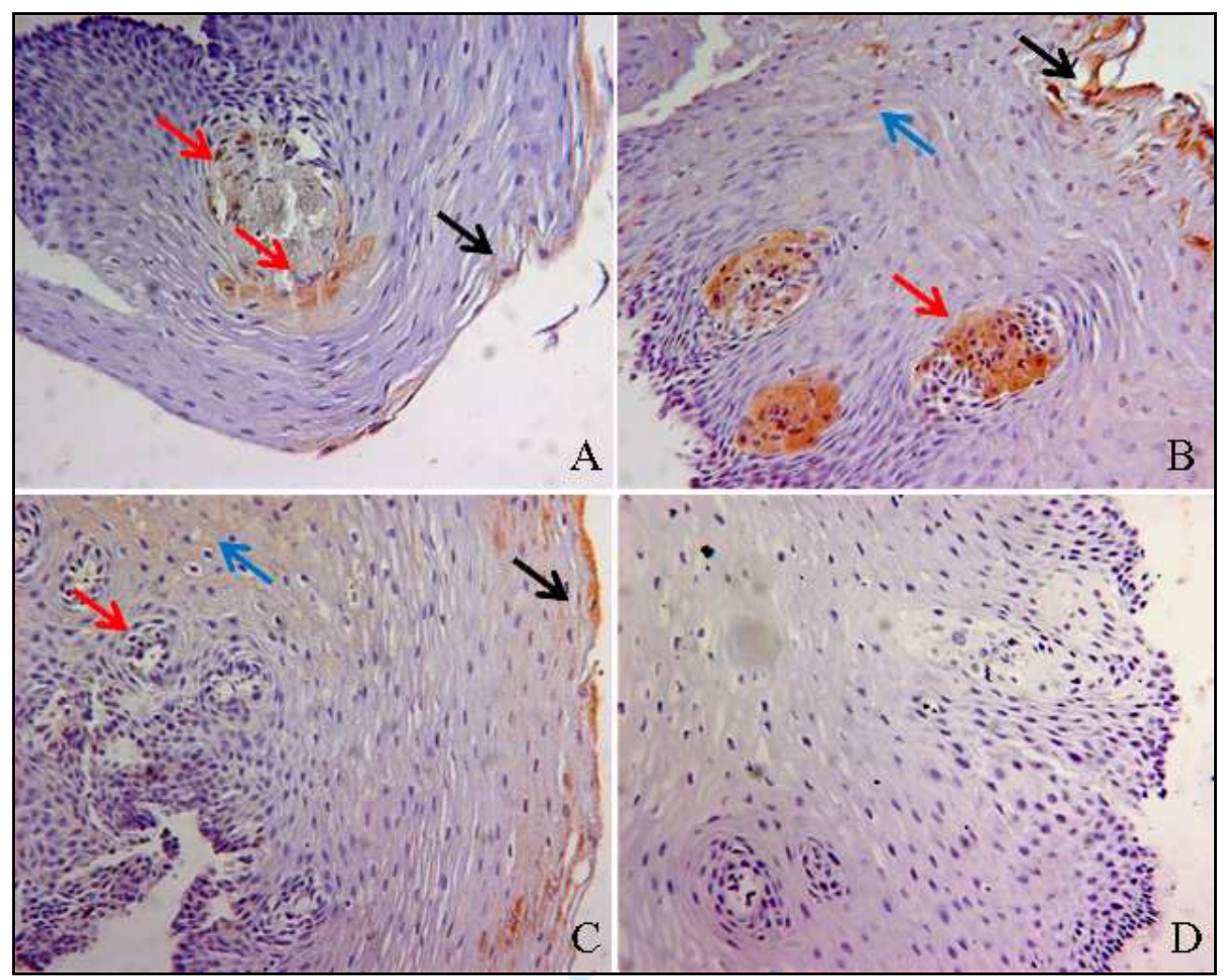

Figure 2: Immunostaining of $\mathrm{CB}_{1}$ receptor in histological sections of esophageal mucosa. Healthy subjects (A) show a weak positive staining localized in mature squamous cells (black arrow) and in connectival papillae (red arrows). NERD patients (B) show $\mathrm{CB}_{1}$ receptor expression in mature squamous cells (black arrow), in squamous cells (blue arrow) and in connectival papillae (red arrow). ERD patients $(\mathrm{C})$ show $\mathrm{CB}_{1}$ positivity only in mature squamous cells (black arrow) and in squamous cells (blue arrows), while connectival papillae appear negative (red arrow). $\mathrm{CB}_{1}$ staining disappeared in esophageal mucosa (D) when $\mathrm{CB}_{1}$ blocking peptide was incubated with $\mathrm{CB}_{1}$ antibody. 

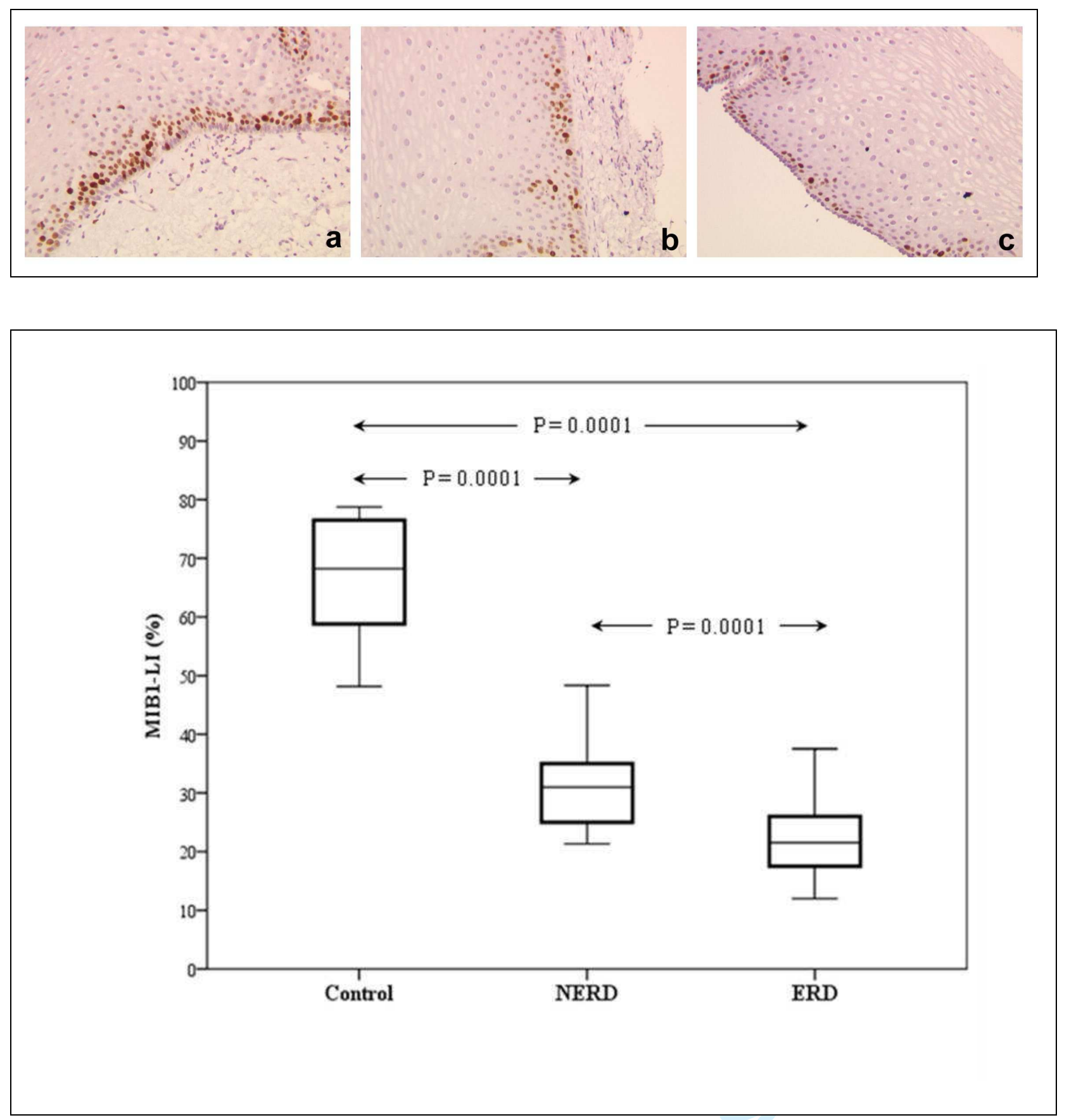

Figure 3: MIB1 immunostaining of histological sections from healthy control (a), and NERD (b) and ERD (c) patients. Box plots of MIB-1 label index (LI), LI median (bold line in the box), and interquartile range (upper and lower lines of the box) in human esophageal mucosa of healthy controls and NERD and ERD patients. 


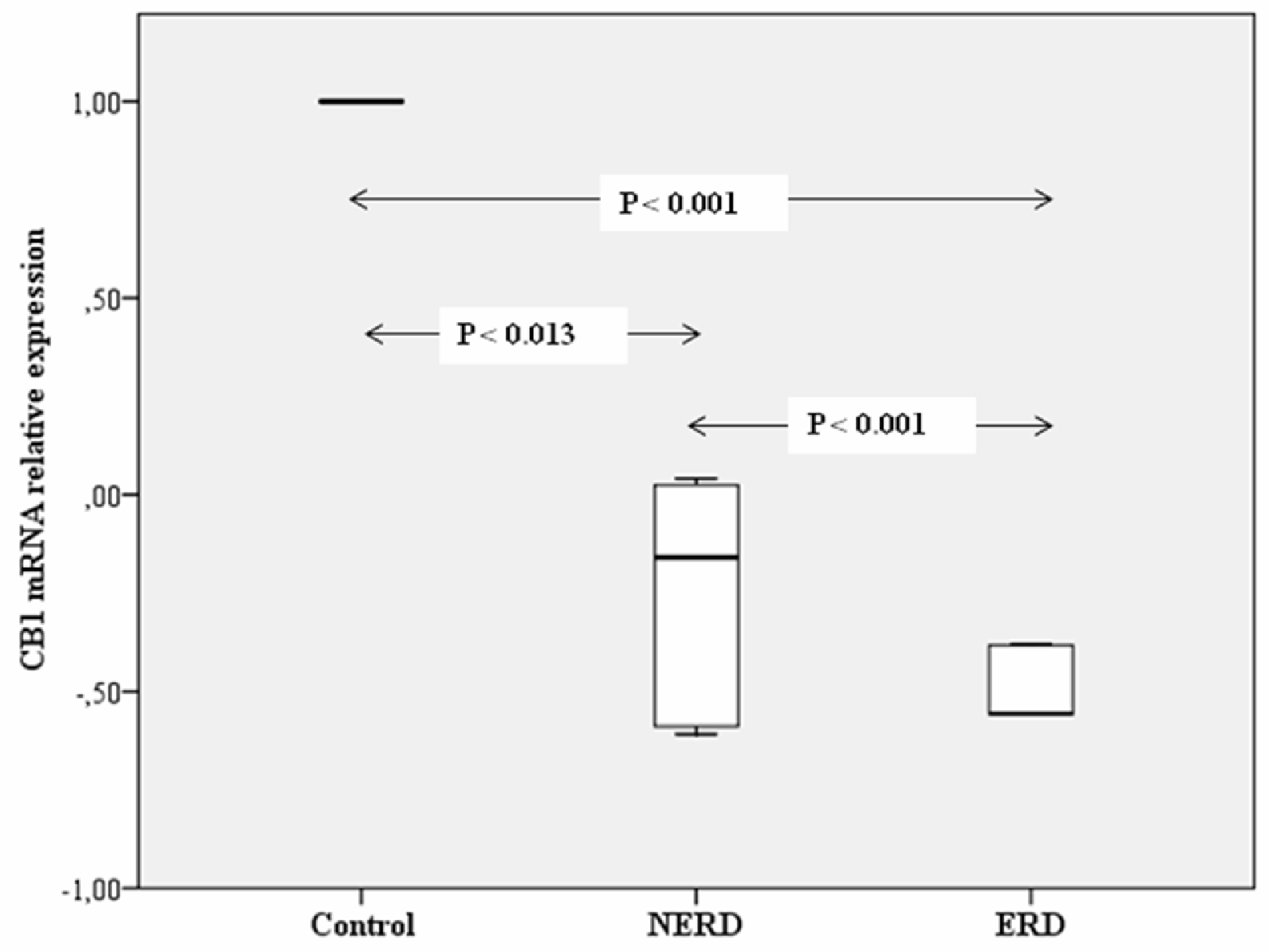

Figure 4: Box plots of relative expression of $\mathrm{CB}_{1}$ mRNA (normalized on GUSB mRNA expression), median (bold line in the box), and interquartile range (upper and lower lines of the box) in human esophageal mucosa of healthy controls and NERD and ERD patients. 


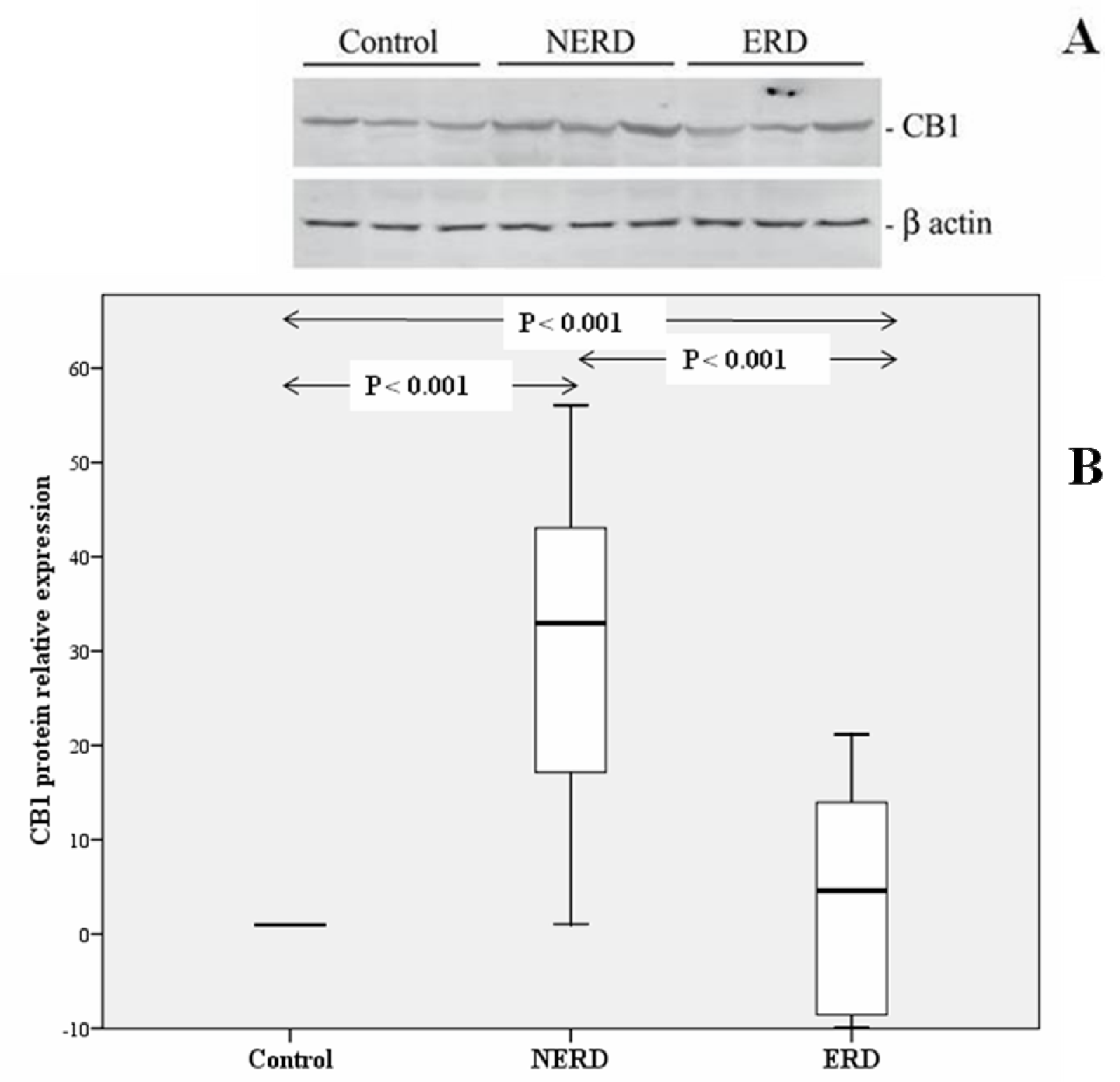

Figure 5: $A$ : $W B$ analysis of $\mathrm{CB}_{1}$ receptor expression in human esophageal mucosa of healthy controls and NERD and ERD patients. The experiment depicted is representative of all the WB experiments done. B: Box plots of relative expression of $\mathrm{CB}_{1}$ protein (normalized on $\beta$-actin protein expression), median (bold line in the box), and interquartile range (upper and lower lines of the box) in human esophageal mucosa of healthy controls and NERD and ERD patients. 


\section{References}

1. Isolauri J, Laippala P. Prevalence of symptoms suggestive of Gastroesophageal reflux disease in an adult population. Ann Med 1995; 27: 67-70.

2. Spechler SJ. Epidemiology and natural history of Gastroesophageal reflux disease. Digestion 1992; 51 (suppl 1): 24-9.

3. Champion G, Richter JE, Vaezi MF, et al. Duodenogastroesophageal reflux: relationship to pH and importance in Barrett's esophagus. Gastroenterology 1994; 107: 747-54.

4. Schlesinger PK, Donahue PE, Schmid B, et al. Limitations of 24-hour intraesophageal pH monitoring in the hospital setting. Gastroenterology 1985; 89: 797-804.

5. Calabrese C, Fabbri A, Bortolotti M, et al. Effect of omeprazole on symptoms and ultrastructural esophageal damage in acid bile reflux. World J Gastroenterol 2005; 11: 187680.

6. Namiot Z, Sarosiek J, Rourk RM, et al. Human esophageal secretion: mucosal response to luminal acid and pepsin. Gastroenterology 1994; 106: 973-81.

7. Sarosiek J, Namiot Z, Piascik R, et al. What part do the mucous cells of submucosal mucous glands play the esophageal pre-epithelial barrier? In: Giuli R, Tytgat GNJ, DeMeester TR. editors. The esophageal mucosa. Amsterdam: Elsevier, 1994: 278-90.

8. Meyers RL, Orlando RC. In vivo bicarbonate secretion by human esophagus. Gastroenterology 1992; 103: 1174-8.

9. Orlando RC. Esophageal epithelial resistance. J ClinGastroenterol 1986; 8 Suppl 1: 12-16

10. Calabrese C, Trere D, Fabbri A, et al. Endoscopic appearance of GERD: putative role of cell proliferation. Dig Liver Dis 2007; 39: 713-19. 
11. Pertwee RG. Pharmacology of cannabinoid CB1 and CB2 receptors. Pharmacol Ther 1997; 74: 129-80.

12. Pertwee RG. Pharmacology of cannabinoid receptor ligands. Curr Med Chem. 1999; 6: 63564.

13. Massa F, Storr M, Lutz B. The endocannabinoid system in the physiology and pathophysiology of the gastrointestinal tract. J Mol Med. 2005; 83:944-54.

14. Croci T, Landi M, Galzin AM, et al. Role of cannabinoid CB1 receptors and tumor necrosis factor-alpha in the gut and systemic anti-inflammatory activity of SR 141716 (rimonabant) in rodents. Br J Pharmacol. 2003; 140:115-22.

15. Borrelli F. Cannabinoid CB(1) receptor and gastric acid secretion. Dig Dis Sci. 2007; 52:3102-3.

16. Wrigth K, Rooney N, Feeney M, et al. Differential expression of cannabinoid receptors in the human colon: cannabinoids promote epithelial wound healing. Gastroenterology 2005; 129: 437-53.

17. Kimball ES, Schneider CR, Wallace NH, et al. Agonists of cannabinoid receptor 1 and 2 inhibit experimental colitis induced by oil of mustard and by dextran sulfate sodium. Am J Physiol Gastrointest Liver Physiol. 2006; 291:G364-71.

18. Massa F, Marsicano G, Hermann H, et al. The endogenous cannabinoid system protects against colonic inflammation. J Clin Invest. 2004; 113:1202-9.

19. Beaumont H, Jensen J, Carlsson A, et al. Effect of delta9-tetrahydrocannabinol, a cannabinoid receptor agonist, on the triggering of transient lower oesophageal sphincter relaxations in dogs and humans. Br J Pharmacol. 2009; 156: 153-62. 
20. Pacini F, Calabrese C, Cipolletta L, Valva MD, Russo A, Savarino V, Vigneri S. Burden of illness in Italian patients with gastro-oesophageal reflux disease. Curr Med Res Opin 2005; 21: $495-502$

21. Johnson LF, DeMeester TR. Twenty-four hour $\mathrm{pH}$ monitoring of the distal esophagus. A quantitative measure of gastroesophageal reflux. Am J Gastroenterol 1974; 62: 325-32.

22. Weusten BL, Roelofs JM, Akkermans LM, et al. The symptom-association probability: an improved method for symptom analysis of 24-hour esophageal $\mathrm{pH}$ data. Gastroenterology 1994; 107: 1741-5.

23. Armstrong D, Bennett JR, Blum LA, et al. The endoscopic assessment of esophagitis: a progress report on observer agreement. Gastroenterology 1996; 111: 85-92.

24. Ismail-Beigi F, Horton PF, Pope CE. Histological consequences of gastro-esophageal reflux in man. Gastroenterology 1970;58: 163-74.

25. Namiot Z, Sarosiek J, Rourk RM, et al. Human esophageal secretion: mucosal response to luminal acid and pepsin. Gastroenterology 1994; 106: 973-981.

26. Sarosiek J, Namiot Z, Piascik R, Hetzel DP, Rourk RM, Edmunds MC, Daniel TM, McCallum RW. What part do the mucous cells of submucosal mucous glands play the esophageal pre-epithelial barrier? In: Giuli R, Tytgat GNJ, DeMeester TR. editors. The esophageal mucosa. Amsterdam: Elsevier, 1994: 278-290

27. Funch-Jensen P, Koch K, Christensen LA, Fallingborg J, Kjaergaard JJ, Paulin Andersen S, et al. Microscopic appearance of the esophageal mucosa in a consecutive series of patients submitted to upper endoscopy. Scand J Gastroenterol 1975;21:65-9.

28. Nandurkar S, Talley NJ, Martin CJ, Adams S. Esophageal histology does not provide additional useful information over clinical assessment in identifying reflux patients presenting for esophagastroduodenoscopy. Dig Dis Sci 2000;45:217-24.

29. Narayani RI, Burton MP, Young GS. Utility of esophageal biopsies in the diagnosis of nonerosive reflux disease. Dis Esophagus 2003;16:187-92. 
30. Cicala M, Emerenziani S, Caviglia R, Guarino MP, Vavassori P, Ribolsi M, et al. Intraoesophageal distribution and perception of acid reflux in patients with non erosive gastroesophageal reflux disease. Aliment Pharmacol Ther 2003;18:605-13.

31. Weusten BL, Roelofs JM, Akkermans LM, Vanberge-Henegouven GP, Smout AJ. Objective determination of $\mathrm{pH}$ thresholds in the analysis of $24 \mathrm{~h}$ ambulatory oesophageal $\mathrm{pH}$ monitoring. Eur Clin Invest 1996;26:151-8.

32. Emerenziani S, Zhang X, Blondeau K, Silny J, Tack J, Janssens J, et al. Gastric fullness, physical activity, and proximal extent of gastroesophageal reflux. Am J Gastroenterol 2005;100:1251-6.

33. Shindlbeck NE, Wiebeck B, Klauser AG, et al. Diagnostic value of histology in non erosive gastroesophageal reflux disease. Gut 1996; 39: 151-4.

34. Tobey NA, Carson JL, Alkiek RA, Orlando RC. Dilated intercellular spaces: a morphological feature of acid reflux damaged human esophageal epithelium. Gastroenterology 1996; 111: 1200-5.

35. Calabrese C, Fabbri A, Bortolotti M, Cenacchi G, Areni A, Scialpi C, et al. Dilated intercellular spaces as a marker of oesophageal damage: comparative results in gastroesophageal reflux disease with or without bile reflux. Aliment Pharmacol Ther 2003; 18 : $525-32$

36. Calabrese C, Treré D, Liguori G, et al. Esophageal cell proliferation in gastroesophageal reflux disease: Clinical-morphological data before and after pantoprazole. World J Gastroenterol 2009; 15: 936-41.

37. Izzo AA, Fezza F, Capasso R, et al. Cannabinoid CB1-receptor mediated regulation of gastrointestinal motility in mice in a model of intestinal inflammation. Br J Pharmacol 2001; 134: $563-70$ 
38. D'Argenio G, Valentini M, Scaglione G, et al. Up-regulation of anandamide levels a san endogenous mechanism and a pharmacological strategy to limit colon inflammation. FASEB J 2006; 20: 568-70

39. Izzo AA, Capasso R, Castagliola A, et al. An endogenous cannabinoid tone attenuates cholera toxin-induced fluid accumulation in mice. Gastroenterology 2003; 125: 765-74

40. Mönkemüller K, Wex T, Kuester D, et al. Interleukin-1beta and interleukin-8 expression correlate with the histomorphological changes in esophageal mucosa of patients with erosive and non-erosive reflux disease. Digestion. 2009;79: 186-95..

41. Sanchez Freire V, Burkhard FC, Kessler TM, et al. Micro RNAs May Mediate the DownRegulation of Neurokinin-1 Receptor in Chronic Bladder Pain Syndrome. AJP 2010; 176: 288-303. 
Immunostaining of $\mathrm{CB} 1$ receptor in histological sections of esophageal mucosa. Healthy subjects (A) show a weak positive staining localized in mature squamous cells (black arrow) and in connectival papillae (red arrows). NERD patients (B) show CB1 receptor expression in mature squamous cells (black arrow), in squamous cells (blue arrow) and in connectival papillae (red arrow). ERD patients

(C) show CB1 positivity only in mature squamous cells (black arrow) and in squamous cells (blue arrows), while connectival papillae appear negative (red arrow). CB1 staining disappeared in esophageal mucosa (D) when CB1 blocking peptide was incubated with CB1 antibody. $224 \times 178 \mathrm{~mm}$ (72 x 72 DPI) 